\title{
The Strategy to Build Educative Interaction in Islamic Education on Online Learning Setting
}

\author{
Rony Sandra Yofa Zebua \\ Master Program of Islamic Education, Universitas Islam Bandung \\ Email: ronysyzebua@gmail.com
}

\begin{abstract}
Nowadays, online learning has forced educational stakeholders to sufficiently involve online learning by handling the fundamental difference from traditional learning platforms. While educative interaction is vital but very limited to online learning, the teachers should condition the new environment to enable the learning process. However, educative interaction on online learning requires exact syntax to help the teachers implement it correctly. Therefore, this study aimed to identify the implementation of educative learning on online learning and formulate the syntax to help teachers create educative interaction. The study focused on Islamic and Character Education subjects. The research method is qualitative, using in-depth interviews to gather the data. The informants were from 2 different elementary schools. The study result revealed two types of syntax for educative interaction on online learning: the syntax of educative interaction on real-time chatting app and syntax of educative interaction on the video conference app. Every syntax has similar general phases: preparation, introduction, core, and closing. However, every phase has different details, adjusted to the service provided by the application used. Eventually, the teachers' competence and spirit and supporting infrastructure become the primary factors in maximizing the interaction. Besides, application choice determines the strategy that will be done.
\end{abstract}

Keywords: Online Educative Interaction, Online Learning, Online Learning Syntax, Islamic Education 


\section{INTRODUCTION}

Technology breakthrough has presented online technology that is impactful for every part of human life, including education (Priatmoko, 2018: 232). Meanwhile, dependency on and bonding nowadays' students is inevitable (Ally, 2019; Sakti, 2020). Students in this digital era are more motivated (Komalasari \& Saripudin, 2017: 184; Mertasari, 2016: 686; Sumardianta \& Kris, 2018) and more likely to imitate any behavior that appeared on online technology (Ormiston, 2011; Panigrahi, Srivastava, \& Sharma, 2018: 7). Therefore, the certainty of online technology enforces educational stakeholders to sufficiently involve online learning (Ally, 2019; Jensen, 2016: 13), one of which presents interesting and fun educative interaction.

Educative interaction is a reciprocal relationship between teachers and students in systematic learning to reach its objectives (Sardiman, 2014 as cited in Hayati, Noer, \& Khoirol, 2015: 118). The educative interaction contains interactive unsure conditioning students' potential development in rational, humanist, and dialogic ways (Mollah, 2015: 255). Thereby, educative interaction proceeds in full of meaningful activities because it contains new norms that the teachers should transfer to the students (Lestari, 2017).

Educative interaction is conducted directly face-to-face. Along with technology development, educative interaction can be implemented through online learning (Harasim, 2002; Rovai, 2004). The interaction on online learning has different characteristics from the traditional class (Bowers \& Kumar, 2015; Hass \& Joseph, 2018). The fundamental difference is on the distant location between the teachers and the students and utilize internet networks for the interaction (Anderson, 2011; Mustofa, Chodzirin, \& Sayekti, 
2019: 153). Thus, Educative interaction is limited (Bowers \& Kumar, 2015: 28; Cole, Shelley, \& Swartz, 2014).

Considering its fundamental difference, the teachers should condition online technology as a new environment that plays an essential role in the learning process. The conditioning can attract students' attention, enable them to save the information, and practice it (Ormrod, Anderman, \& Anderman, 2017: 351; Santrock, 2011: 236-237). Consequently, the teachers are expected to create educative interaction online, which is interesting while also developing students' potency (Wang et al., 2019; Wuensch, Aziz, Ozan, Kishore, \& Tabrizi, 2008).

The establishment of educative interaction is adjusted to the subjects' characteristics. In this study, the focused study is Islamic and Character Education subject called PAI subject. The PAI subject's characteristics emphasize the balance between faith and worship for the world and the life hereafter (Irsad, 2016; Mahmudi, 2019). There are several activities (1) knowledge transfer, understanding and story or history, (2) faith internalization and obedience, (3) training for worship and social skills, and (4) memorization (Irsad, 2016).

Every educative interaction requires exact syntax to help the teachers implement it correctly. However, according to past literature, it is not found studies focusing on the syntax for online learning. Most studies focused on traditional class context when analyzing educative interaction on PAI subjects (e.g., Hayati et al., 2015; Nuroni \& Khambali, 2016; Saifuddin, 2018) and the strategy to develop value-based interactive multimedia to build educative interaction (Cahyono, 2019; Komalasari \& Saripudin, 2017). 
On the other hand, some studies focus on online learning context, dealing with basic principles for educative interaction such as introduction, student participation, and facilities (Robinson, Sheffield, Phillips, \& Moore, 2017). In comparison, some other studies compared educative interaction in the traditional and online context and common strategy in developing educative interaction on online learning (Rapchak, 2018; Shu \& Gu, 2018). A study conducted by Ally (2019) proposed that the teachers should own competencies to manage and create educative interaction on online learning. However, the proposed competence still lacks presenting educative interaction skills and knowledge (Mishra, Gupta, \& Shree, 2020).

Therefore, this study aimed to identify the implementation of educative learning on online learning and formulate the syntax to create educative interaction, especially for PAI subjects. Bandura stated that the identification and syntax formulation was conducted using Social Cognitive Theory approach (Bandura, 1999). The study is expected to give PAI teachers or other subject teachers insights, which have similar characteristics to PAI subjects about building educative interaction on online learning.

\section{METHODS}

This study is a qualitative study that used an in-depth interview to gather the data. There were six initial questions to be asked to the informants, which expanded based on the informants' responses. The interview process was conducted in August 2020. This study investigated the experiences of 2 PAI teachers who are utilizing online learning platforms in this pandemic era. Each teacher represented one school. Further data about the teachers as the informants in this study are presented in Table 1. 
Table 1. Informant data

\begin{tabular}{lll}
\hline No & Informant & Information about Informants \\
\hline 1 & Teacher 1 & $\begin{array}{l}\text { Teaching PAI in SDN 366 IRK Bandung Class V \& VI } \\
\text { with teaching experience for ten years } \\
\text { Teaching PAI in SD Al Muslim Tambun District Bekasi } \\
\text { class IV \& V with teaching experience for 13 years }\end{array}$ \\
\hline
\end{tabular}

The informants were chosen based on the teacher's interest to support online learning. The information about teachers' interest in online learning was based on the PAI teacher chatting community's recommendation in the greater Bandung. Therefore, the sampling technique applied is a purposive sampling (Sugiyono, 2018: 301).

The data analysis was conducted in three steps: 1) listen carefully to the interview recordings one by one, 2) Analyze the data and synthesize the strategy of educative interaction for each school, 3) formulate the strategy of educative interaction online learning in the form of learning syntax.

\section{DISCUSSION}

The educative interaction on online learning can be practiced using real-time chatting apps (e.g., Whatsapp), virtual class apps (e.g., Google Classroom), video conference apps (e.g., Zoom Meeting and Google Meet), and other similar apps. Based on all informants' information, learning activities' implementation is adjusted to the students' situation and capability, especially on providing the peripherals and internet connection facilities. For this reason, the teachers' competence and interest are required to maximize it (Ally, 2019; Jevtic, 2014: 79; Mishra et al., 2020). Besides, parents' understanding, supports are also required. The parents' role will help the children's education 
process, especially for online learning (Şahinkayasi \& Kelleci, 2013: 119; Sahroni \& Latief, 2019: 157).

Education interaction in learning activities is divided into three phases: introduction, core, and closing phase (Mujizatullah, 2014: 102; Nurussalami, 2017: 129; Pramujiono \& Nurjati, 2017: 152). According to the findings of this study, educative interaction in online learning also needs preparation. The detailed findings for each school are explored in the following sub-section.

\section{Educative Interaction in SDN 366 IRK Bandung}

Online learning for PAI subject in SDN 366 IRK Bandung using Zoom Meeting. Whatsapp, which is utilized mostly for the preparation and enrichment phase, is conducted outside scheduled learning time. This strategy potentially attracts students' attention (Ormrod et al., 2017: 251) and motivates them to be more enthusiastic in involving the learning process (Schunk \& DiBenedetto, 2020).

The online interaction is started before the learning schedule is started. The teacher told the students through the message about the learning materials and sharing Quran verses, which will be read through Whatsapp. The educative interaction is through Zoom Meeting starting by (1) teachers open the activity by greeting, (2) students' group which is assigned to give inspiring words and full of spirit, (3) teachers greet the students and ask their condition, (4) teachers give the material using video or story related to them being discussed, (5) then the students are asked to re-tell the story or practice the procedure displayed in the video, (6) teachers close the activity by giving conclusions, (7) teachers remind the students to implement and habituate what has been learned and also to be actively involved in the enriching activity. 
Generally, the interaction conducted can enable students to save valuable knowledge and skills (Santrock, 2011).

\section{Educative Interaction in SD Al Muslim Tambun Bekasi}

The online educative interaction for PAI subjects in SD Al Muslim Tambun Bekasi is done through Google Classroom, Google Form, and Google Meet. The use of Google Meet is specialized for students on IV-VI grades, while Google Classroom is used for students on I-III grades. Google Form is used for activity reports and daily worship, which is called the daily activity report. The student must fill out their daily activity report once they have done it.

The implementation of educative interaction through Google Meet in SD Al Muslim Tambun Bekasi, are (1) teachers have been present in the Google Meet before the learning activity is started, (2) the teachers say hello to the students and motivate them to behave and do their worship with fun way, (3) as the time is on, the teachers greet the student with salam, (4) the teachers ask their worship routinely, (5) the teachers give the learning materials using fun language and completed with easy-to-understand, (6) the teachers close the learning activity by reminding the students about honesty and fulfill their daily activity report after they have done the worship.

The teacher's emphasis before the learning activity becomes one of the most crucial ways to improve students' trust and confidence toward teachers (Schunk \& DiBenedetto, 2020). Therefore, the students will be more motivated to give attention and wholeheartedly to practice their learning materials (Ormrod et al., 2017). 


\section{The Synthesis of Educative Interaction on Online Learning}

Based on the implementation of educative interaction in 2 elementary schools above, it can be stated that there is no difference in the phases for educative interaction syntax on online learning. The phases are divided into three phases: introduction, core phase, and closing phase. Even though the phases are similar, educative interaction needs more skills and creativity to present enjoyable activities (Ally, 2019). The teachers should show not monotonous activities and utilize short videos and exciting pictures with color variation to stimulate students.

Besides, it requires the preparation phase for online learning, which is done before the learning activity started. The preparation phase will help the students be well prepared and self-confident (Schunk \& DiBenedetto, 2020) and improve their attention to the learning activities (Ormrod et al., 2017). In this phase, the teacher reminds students about learning manners to maximize the expected education interactions.

The educative interaction should meet the aspects that enable the students to remember and understand the knowledge, internalize, exercise, and motivate them to learn (Santrock, 2011). One of the efforts to motivate the students is by using the discussion method and utilize various media such as video, images, recording, and a combination of exciting and not boring colors. Besides being motivated, this strategy can also nurture their attention to remember and understand the material more easily (Ormrod et al., 2017: 251). Exercise and evaluation activities can also be done in a fun way in real-time by using Quizizz and Kahoot or similar applications.

In the closing phase, the teacher should always remind and inculcate Ihsan's values to always feel supervised by Allah (Idharudin, Alim, \& Al 
Kattani, 2019: 61). The approach is expected to nurture self-control, such as feel guilty when doing deviation (Josephson \& Hanson, 2004: 4), and to nurture honesty, integrity, and responsibility (Schuller, 2004: 51). So, students can be motivated to be earnest and enthusiastic in carrying out assignments or exercises independently and practice worship honestly as best as possible.

One of the schools conducts enrichment outside of the scheduled activities. However, this study focuses on scheduled time activities and all the preparation activities before the learning schedule. The educative interaction syntax is divided into two types, educative interaction syntax that uses video conference app such as Zoom Meeting or Google Meet and the real-time chatting app such as Whatsapp. The other application is used only to support the primary activity. Besides, Whatsapp is also used for communication media and anticipates an obstacle related to the internet connection when a learning activity occurs. The educative interaction syntax for video conference apps is presented in Table 2.

Table 2. Syntax of educative interaction on Video Conference App

\begin{tabular}{ll}
\hline Phase & Activity Steps \\
\hline $\begin{array}{l}\text { Preparation } \\
\text { through }\end{array}$ & $\begin{array}{l}\text { 1. The teachers give information about the learning } \\
\text { materials. }\end{array}$ \\
Whatsapp). & 2. If the learning materials about worship exercise, the \\
teachers will send videos or pictures containing the \\
worship procedure. \\
3. The teachers ask the student to prepare themselves. \\
4. The teachers remind the students about manners of \\
learning (sincere intention, neat dressing, activate the \\
camera, and being solicitous on following teachers \\
direction) \\
1. The teachers should present before the learning time is \\
started. \\
2. The teachers greet the students and ask for their \\
readiness and the condition of each student who has just \\
come to the video conference. \\
3. The teachers should open the learning activity by greeting
\end{tabular}




and motivate them about worship and behavior using
attractive and friendly language.
4. The teachers ensure all the students and the teachers to
activate their video camera.
5. The teachers allow the students' group, which gets the
task to give inspiring words to attract students' attention.
6. A short dialogue about the previous materials to the
students, alternately according to teachers' permission
1. The teachers show a short video or picture or tell a story
and present the material interactively according to the
subject.
2. The teachers ask the students to have an active discussion
or ask the student to practice the worship skills shown
directly.
3. The teachers ask the students to write a conclusion or key
points from the discussion or evaluate using Quizizz,
Kahoot, or Google Form.
4. While waiting for the evaluation process, the teachers
allow the student to ask directly about materials.
1. The teachers conclude and motivate the students to
behave well and worship routinely and remind them
about Allah's supervision.
2. The teachers remind the students to fulfill daily reports
on the Google Form or other applications honestly and the
documentation.
3. The teachers ask the students to re-tell the key points of
the materials just given through voice note (Whatsapp)
once the learning activities are ended.
4. Greeting and say goodbye to the teachers.

The syntax for the video conference apps above can be adapted to formulate the syntax in real-time chat apps. The proposed syntax is expected to be used by institutions having difficulty organizing online learning via video conference apps. The educative interaction syntax on real-time chatting apps (Whatsapp) is presented in Table 3. 
Mudarrisa: Jurnal Kajian Pendidikan Islam, Vol. 12, No. 2, 2020

Table 3. Educative interaction syntax on Whatsapp App

\begin{tabular}{|c|c|}
\hline Phase & Activity Steps \\
\hline Preparation & $\begin{array}{l}\text { 1. The teachers give information about the learning } \\
\text { materials. } \\
\text { 2. If the materials are related to worship practice, the } \\
\text { teachers send a video or pictures about the worship } \\
\text { procedure. } \\
\text { 3. The teachers ask the student to prepare themselves. }\end{array}$ \\
\hline Introduction & $\begin{array}{l}\text { 1. Greeting and say hello to the students. } \\
\text { 2. The teachers check the students' readiness. } \\
\text { 3. A short dialogue about the previous materials through } \\
\text { voice note: The students' voice note runs alternately. }\end{array}$ \\
\hline Core & $\begin{array}{l}\text { 1. The teachers ask the students to pay attention or watch } \\
\text { the short video or pictures shared in the group. } \\
\text { 2. The teachers allow a short dialogue about the materials } \\
\text { being discussed through voice note alternately based on } \\
\text { teachers' permission, or } \\
\text { 3. Practice the worships as the example given from the video } \\
\text { or pictures (every student makes documentation and } \\
\text { sends it to Google Form). } \\
\text { 4. The teachers ask the students to give a short conclusion } \\
\text { or points related to the materials. Meanwhile, the } \\
\text { students can ask anything about the materials. } \\
\text { 5. The teachers send answers to the students' questions } \\
\text { using voice notes. }\end{array}$ \\
\hline Closing & $\begin{array}{l}\text { 1. The teachers ask the students to collect all the } \\
\text { conclusions being written through Whatsapp or Google } \\
\text { Classroom. } \\
\text { 2. The teachers remind the students to fulfill their daily } \\
\text { reports on Google Form or other applications honestly and } \\
\text { with the documentation. } \\
\text { 3. The teachers send voice notes about encouragement to } \\
\text { behave and routinely conduct their worship while also } \\
\text { reminding them about Allah's supervision. } \\
\text { 4. Closing greets from the teachers. }\end{array}$ \\
\hline
\end{tabular}

The syntax for every phase is not rigid on the order (Joyce, Weil, \& Calhoun, 2015) to enable the teachers to adjust the actual condition and situation. Both syntaxes have a relatively significant difference in the skill exercise aspect. The practice activities are only supervised and guided directly through video conference. Meanwhile, the application app should be thorough 
documentation. To get more effective learning activities, strengthening can be through motivation and self-confidence required by the students (Schunk \& DiBenedetto, 2020). Therefore, besides the skills of managing the class, the teachers should show enthusiasm and interest in running the activities.

\section{CONCLUSION}

Educative interaction in online learning can be done through various platforms. But the competence and spirits from the teachers become the primary factors in maximizing the interaction. Then, the application choice will determine the strategy that will be done. Besides, supports from infrastructure also plays an important role in enabling the online learning activity.

This study identified several schools that have done educative interaction for PAI subjects. Based on the findings, this study proposed two types of syntax for educative interaction online: the syntax of educative interaction on real-time chatting app and syntax of educative interaction on the video conference app. Every syntax has similar general phases: preparation, introduction, core, and closing. However, every phase has different details, adjusted to the service provided by the application used.

This study is preliminary research that needs further development, including identifying and formulating syntax for other applications. This study also focused on PAI learning so that further studies can be implemented on other subjects with different characteristics. The proposed syntax also needs more detailed technical procedures to be tested to more other schools to get more robust results. 
Mudarrisa: Jurnal Kajian Pendidikan Islam, Vol. 12, No. 2, 2020

\section{REFERENCES}

Ally, M. (2019). Competency Profile of the Digital and Online Teacher in Future Education. International Review of Research in Open and Distance Learning, 20(2), 302-318. https://doi.org/10.19173/irrodl.v20i2.4206

Anderson, T. (2011). The Theory and Practice of Online Learning. Edmonton: AU Press.

Bandura, A. (1999). Social Cognitive Theory: An Agentic Perspective. Asian Journal of Social Psychology, 2, 21-41. https://doi.org/10.1111/1467839x.00024

Bowers, J., \& Kumar, P. (2015). Students' Perceptions of Teaching and Social Presence: A Comparative Analysis of Face-to-Face and Online Learning Environments. International Journal of Web-Based Learning and Teaching Technologies, 10(1), 27-44. https://doi.org/10.4018/ijwltt.2015010103

Cahyono, G. (2019). Interactive Media Development of Procedures for Prayer

(Tara Shalat) Based on Adobe Flash in Improving the Skills of Madrasah

Ibtidaiyah Prayers. Mudarrisa: Jurnal Kajian Pendidikan Islam, 11(2), 159182. https://doi.org/10.18326/mdr.v11i2.159-182

Cole, M. T., Shelley, D. J., \& Swartz, L. B. (2014). Online Instruction, Elearning, and Student Satisfaction: A three Year Study. International Review of Research in Open and Distance Learning, 15(6), 111-131. https://doi.org/10.19173/irrodl.v15i6.1748

Harasim, L. (2002). The Virtual University: A State of the Art. Advances in Computers, 55, 1-47. https://doi.org/10.1016/s0065-2458(01)80025-5

Hass, A., \& Joseph, M. (2018). Investigating Different Options in Course Delivery - Traditional vs. Online: is There Another Option? International 
Mudarrisa: Jurnal Kajian Pendidikan Islam, Vol. 12, No. 2, 2020

Journal of Information and Learning Technology, 35(4), 230-239. https://doi.org/10.1108/IJILT-09-2017-0096

Hayati, N., Noer, M. A., \& Khoirol, W. (2015). Kemampuan Mengelola Interaksi Edukatif Guru Pendidikan Agama Islam. Al-Hikmah: Jurnal Agama Dan Ilmu Pengetahuan, 12(2), 117-131. https://doi.org/10.25299/jaip.2015.vol12(2).1452

Idharudin, A. J., Alim, A., \& Al Kattani, A. H. (2019). Penerapan Model Pendidikan Akhlak Syaikh Utsaimin di SDIT Al-Hidayah Bogor. Jurnal As-Salam, 3(3), 53-66. https://doi.org/10.37249/as-salam.v3i3.137

Irsad, M. (2016). Pengembangan Kurikulum Pendidikan Agama Islam Di Madrasah (Studi Atas Pemikiran Muhaimin). Iqra', 2(1), 230-268. Retrieved from http://dx.doi.org/10.30659/jpai.2.1.89-105

Jensen, E. B. (2016). Peer-Review Writing Workshops in College Courses: Students' Perspectives about Online and Classroom-Based Workshops. Social Sciences, 5(4), 1-17. https://doi.org/10.3390/socsci5040072

Jevtic, B. (2014). Teachers' Pedagogical Actions Affecting The Moral Development of Personality. Problems of Education In the 21st Century, 58, 67-81. Retrieved from http://www.scientiasocialis.lt/pec/node/883

Josephson, M. S., \& Hanson, W. (2004). The Power of Character (2nd ed.). Indiana: Unlimited Publishing LLC.

Joyce, B. R., Weil, M., \& Calhoun, E. (2015). Model of Teaching (9th ed.). New York: Pearson.

Komalasari, K., \& Saripudin, D. (2017). Value-Based Interactive Multimedia Development through Integrated Practice for The Formation of Students' Character. TOJET: The Turkish Online Journal of Educational Technology, 
16(4), 179-186.

Lestari, A. (2017). Konsep Guru Dan Anak Didik Dalam Pendidikan Akhlak Menurut Ibnu Maskwaih. Jurnal Tarbawi, 14(2), 123-134. https://doi.org/10.34001/tarbawi.v14i2.618

Mahmudi. (2019). Pendidikan Agama Islam dan Pendidikan Islam Tinjauan Epistemologi, Isi, dan Materi. TA'DIBUNA: Jurnal Pendidikan Agama Islam, 2(1), 89-105. https://doi.org/10.30659/jpai.2.1.89-105

Mertasari, N. M. S. (2016). Media Online Untuk Asesmen Pendidikan Karakter Terpadu. Jurnal Sains Dan Teknologi, 5(1), 683-691. https://doi.org/10.23887/jst-undiksha.v5i1.8273

Mishra, L., Gupta, T., \& Shree, A. (2020). Online Teaching-Learning in Higher Education during Lockdown Period of COVID-19 Pandemic. International Journal of Educational Research Open, (100012). https://doi.org/10.1016/j.ijedro.2020.100012

Mollah, M. K. (2015). Konsep Interaksi Edukatif Dalam Pendidikan Islam Dalam Perspektif Al-Qur'an. Jurnal Pendidikan Agama Islam, 3(2), 235256. https://doi.org/10.15642/pai.2015.3.2.235-256

Mujizatullah. (2014). Implementasi Pendidikan Karakter Pada Madrasah Aliyah Puteri Aisyiah di Palu. Al-Qalam, 20(1), 97-108. https://doi.org/10.31969/alq.v20i1.181

Mustofa, M. I., Chodzirin, M., \& Sayekti, L. (2019). Formulasi Model Perkuliahan Daring Sebagai Upaya Menekan Disparitas Kualitas Perguruan Tinggi. Walisongo Journal of Information Technology, 1(2), 151160. https://doi.org/10.21580/wjit.2019.1.2.4067

Nuroni, E., \& Khambali. (2016). Implementasi Pembentukan Karakter pada 
Peserta Didik di MI Asih Putera Kota Cimahi. Ta'dib: Jurnal Pendidikan Islam, 5(1), 61-70. https://doi.org/10.29313/tjpi.v5i1.2032

Nurussalami. (2017). Pengelolaan Pembelajaran Pendidikan Akidah Akhlak Pada MTsS Darul Aman Aceh Besar. Jurnal Intelektualita, 4(1), 123-139.

Ormiston, M. (2011). Creating a DigitalRich Classroom: Teaching $\mathcal{E}$ Learning in a Web 2.0 World. Bloomington: Solution Tree Press.

Ormrod, J. E., Anderman, E. M., \& Anderman, L. (2017). Educational Psychology Developing Learners (9th ed.). Essex: Pearson Education Limited. Panigrahi, R., Srivastava, P. R., \& Sharma, D. (2018). Online learning: Adoption, Continuance, and Learning outcome - A review of the

literature. International Journal of Information Management, 43, 1-14. https://doi.org/10.1016/j.ijinfomgt.2018.05.005

Pramujiono, A., \& Nurjati, N. (2017). Guru sebagai Model Kesantunan Berbahasa dalam Interaksi Instruksional di Sekolah Dasar. Guru Sebagai Model Kesantunan Berbahasa Dalam Interaksi Instruksional Di Sekolah Dasar, 2(2), 143-154. https://doi.org/10.17509/mimbardik.v2i2.8624

Priatmoko, S. (2018). Memperkuat Eksistensi Pendidikan Islam Di Era 4.0. Ta'lim, 1(2), 221-239. https://doi.org/10.29062/ta'lim.v1i2.948

Rapchak, M. E. (2018). Collaborative Learning in an Information Literacy Course: The Impact of Online Versus Face-to-Face Instruction on Social Metacognitive Awareness. Journal of Academic Librarianship, 44(3), 383390. https://doi.org/10.1016/j.acalib.2018.03.003

Robinson, H. A., Sheffield, A., Phillips, A. S., \& Moore, M. (2017). "Introduction to Teaching Online": Usability Evaluation of Interactivity in an Online Social Constructivist Course. TechTrends, 61(6), 533-540. 
https://doi.org/10.1007/s11528-017-0187-z

Rovai, A. P. (2004). A Constructivist Approach to Online College Learning. Internet and Higher Education, 7(2), 79-93. https://doi.org/10.1016/j.iheduc.2003.10.002

Şahinkayasi, Y., \& Kelleci, Ö. (2013). Elementary School Teachers' Views on Values Education. Procedia - Social and Behavioral Sciences, 93, 116-120. https://doi.org/10.1016/j.sbspro.2013.09.162

Sahroni, S., \& Latief, A. M. (2019). Program Evaluation - Strengthening Character Education In Integrated Islamic Junior Secondary School. JKP | Jurnal Kepemimpinan Pendidikan, 2(1), 152-164. https://doi.org/10.22236/jkpuhamka.v2i1.3803

Saifuddin. (2018). Implementasi Pendidikan Nilai Melalui Active-Learning Dalam Tradisi Pondok Pesantren An-Nur. CENDEKIA: Media Komunikasi

Penelitian Dan Pengembangan Pendidikan Islam, 10(02), 171-182. https://doi.org/10.37850/cendekia.v10i02.74

Sakti, M. N. S. F. (2020). Moslem Social Media 4.0: Argumen Islam Terhadap Fenomena Sosial Media di Era Industri 4.0. Jakarta: Elex Media Komputindo.

Santrock, J. W. (2011). Educational Psychology (5th ed.). New York: McGrawHill.

Schuller, T. R. R. H. (2004). The Essential Qualities of a Good Person. In M. S. Josephson \& W. Hanson (Eds.), The Power of Character (2nd ed., pp. 48-57). Indiana: Unlimited Publishing LLC.

Schunk, D. H., \& DiBenedetto, M. K. (2020). Motivation and social cognitive theory. Contemporary Educational Psychology, 60(101832), 1-10. 
Mudarrisa: Jurnal Kajian Pendidikan Islam, Vol. 12, No. 2, 2020

https://doi.org/10.1016/j.cedpsych.2019.101832

Shu, H., \& Gu, X. (2018). Determining The Differences Between Online and Face-to-Face Student - Group Interactions in a Blended Learning Course. Internet and Higher Education, 39, 13-21. https://doi.org/10.1016/j.iheduc.2018.05.003

Sugiyono. (2018). Metode Penelitian Kuantitatif, Kualitatif, dan Kombinasi (Mixed Method). Bandung: Alfabeta.

Sumardianta, J., \& Kris, W. (2018). Mendidik Generasi Z dan A. Jakarta: Grasindo.

Wang, C., Hsu, H. K., Bonem, E. M., Moss, J. D., Yu, S., Nelson, D. B., \& Levesque-bristol, C. (2019). Need Satisfaction and Need Dissatisfaction: A Comparative Study of Online and Face-to-Face Learning Contexts. Computers in Human Behavior, 95, 114-125. https://doi.org/10.1016/j.chb.2019.01.034

Wuensch, K. L., Aziz, S., Ozan, E., Kishore, M., \& Tabrizi, M. H. N. (2008). Pedagogical Characteristics of Online and Face-to-Face Classes. International Journal on ELearning, 7(3), 523-532. 